\title{
Solid-phase enzyme modification via affinity chromatography
}

\author{
Erkan Türker Baran ${ }^{\mathrm{a}, 1}$, Nazmi Özer ${ }^{\mathrm{b}}$, Vasif Hasirci ${ }^{\mathrm{a}, *}$ \\ ${ }^{a}$ Department of Biological Sciences, Biotechnology Research Unit, Middle East Technical University, 06531 Ankara, Turkey \\ ${ }^{\mathrm{b}}$ Hacettepe University, Faculty of Medicine, Department of Biochemistry, 06100 Ankara, Turkey
}

Received 25 February 2003; received in revised form 5 June 2003; accepted 10 June 2003

\begin{abstract}
In the present study antileukemic enzyme L-asparaginase (ASNase) and catalase (as a model enzyme) were modified in solid-phase with activated polyethylene glycol $\left(\mathrm{PEG}_{2}\right)$ by using ligand-immobilized affinity column systems L-asparagineSepharose CL-4B and Procion red-Sepharose CL-4B, respectively. Studies on change of specific activity with modification time showed negligible differences between batches of modified catalase. Modification of ASNase for $1 \mathrm{~h}$ resulted in $50.2 \%$ recovery of the specific activity and the attachment of 69 molecules of $\mathrm{PEG}_{2}$ per molecule of ASNase forming 'PEGylated ASNase'. Sequential modification of ASNase by activated PEG and heparin resulted in coupling of about nine molecules of heparin per molecule of PEGylated ASNase. Intravenous (i.v.) administration of $\mathrm{PEG}_{2}$-modified ASNase showed prolonged presence in the blood circulation and no adverse effects or symptoms of anaphylaxis were observed in presensitized mice. (C) 2003 Elsevier B.V. All rights reserved.
\end{abstract}

Keywords: Enzymes; L-asparaginase

\section{Introduction}

Chemical modification of proteins became common in the late 1950s. The techniques were originally developed for use in the structural analysis of proteins. Since the late 1970s, many articles on the chemical modification of proteins with synthetic macromolecules have been published [1]. Modifica-

\footnotetext{
*Corresponding author. Tel.: +90-312-210-5180; fax: +90312-210-1289.

E-mail address: vhasirci@metu.edu.tr (V. Hasirci).

${ }^{1}$ Present address: Department of Polymer Engineering, University of Minho, Campus de Azurém, 4800-058, Guimarães, Portugal.
}

tion of proteins with polyethylene glycol (PEG), a linear, non-toxic, non-immunogenic and amphipathic polymer has been studied as a potential means to add unique properties to proteins. The technique of modification with polyethylene glycol has opened a new avenue towards reduction of the immunoreactivity and prolonged the clearance time of foreign protein drugs used in biomedical applications [2-4].

The term 'site-specific modification' is used to describe the methods for chemical modification of bioactive proteins through their carbohydrate residues located on the outside of the active sites. Immobilization of glycoproteins on a support, using these techniques, through their carbohydrate residues resulted in high stability and activity. The binding 
sites of enzymes and antibodies are located in the protein moieties hence, the immobilization of the glycoproteins through their carbohydrate residues do not only stabilize the protein conformation but also provide better access of the substrate to the active sites $[5,6]$.

In one such study, Petkov et al. [7] achieved a successful immobilization of glucose oxidase via activation of its carbohydrate residues by oxidation with galactose oxidase. The oxidized enzyme was coupled to hydrazine derivatives of $O$ - $\alpha$-D-galactosyl Sepharose-H1000 or Sepharose-4B. Glucose oxidase immobilized by this procedure showed higher activity than the glucose oxidases modified using other immobilization procedures.

Likewise, site-specific and site-directed modification of antibodies may be achieved by chemical or enzymatic oxidation of the carbohydrate residues located remote from the binding sites of the antibody, on the Fc fragment. Immobilization through this region does not usually impair the immunological activity of the antibody [8].

The protection of the activity of the enzyme during the immobilization procedure by the presence of competitive inhibitor has been reported by several researchers. In one such study, Blanco et al. [9] showed that multipoint covalent attachment of enzyme in the presence of competitive enzyme inhibitor to activated (aldehyde generated) support preserved the enzyme in fully active form. The inhibitor bound on the active centre of the enzyme protects the enzyme from distorting conformational changes by multipoint covalent attachment to aldehyde agarose gels.

In addition to protecting active sites, a different application of oriented immobilization of enzymes was demonstrated by Turkova et al. [10]. In this study, site specific crosslinking of antichymotrypsin with glutaraldehyde was achieved after biospesific adsorption of enzyme to natural inhibitor, antilysine immobilized on Sepharose 4B. This antilysinechymotrypin crosslinked complex was further used as biospecific adsorbent for isolation of immunoglobulin $G$ against antigenic sites outside of active site of chymotrypsin.

There are several approaches to oriented immobilization of enzymes using the power of molecular biology, including: (a) binding of site-specifically biotinylated enzymes to membrane immobilized streptavidin bridge; (b) fusion protein technology coupled with affinity tags on membranes; and (c) site-directed mutagenesis to introduce a cysteine into a protein with subsequent $\mathrm{SH}$-specific coupling to the membrane support [11].

Increased circulatory half-life of some proteins upon modification with PEG or other high molecular mass polymers may be attributed to the decreased clearance by glomerular filtration by the kidney $[12,13]$. Conjugation of PEG to proteins caused a great increase in the size of the protein, presumably due to the hydration of PEG. Increasing the extent of modification increased the size of the protein, thereby decreasing the amount lost due to glomerular filtration.

Another possible mechanism for the prolonged half-life in the circulation includes the different actions of various proteases, such as trypsin and chymotrypsin, on the unconjugated form of ASNase. A third potential mechanism for PEG-asparaginase's prolonged half-life may be related to its decreased clearance by the reticuloendothelial system, which is responsible for the clearance of foreign proteins $[14,15]$.

In order to accomplish effective modification of a bioactive agent with PEG, a balance must be maintained between the number of PEG chains (of a given molecular mass) which are required to prevent immunogenicity, and the decrease in enzyme activity resulting from the number of PEGs bound to or in proximity of active sites. In situations where standard PEG modification may block too many active sites on the target macromolecule, a higher molecular mass, branched PEG (U-PEG) would, in concept, be better because it would require only half the attachment sites to provide an equal coverage [16].

PEG-conjugated proteins are expensive due to their difficult and long purification steps. Ultrafiltration is the major method to eliminate the unbound methoxy polyethylene glycol (mPEG) but it has a tendency to block the pores of the membrane filter because of its random coil structure that is well hydrated in aqueous solution. With mPEGs having an MW of $5000 \mathrm{Da}$ or greater, it was noted that the ultrafiltration membrane was blocked rapidly owing 
to clogging of the pores by free mPEG [17]. The major drawback of pressure-driven membrane processes, ultrafiltration in particular, is the build up of material at the membrane-solution interface [18].

In this study an alternative enzyme modification was tested; catalase and L-asparaginase were immobilized on an affinity matrix by adsorption on a biosorbent and to this structure activated polyethylene glycol chains were added. This novel method offers a means of protection of active sites during a modified process by orienting the enzyme active site towards the solid-phase and the presence of the solid support offers a convenient way of removing the unused reactive reagents without a need for excessive dialysis or ultrafiltration. Sequential modification of asparaginese first with PEG and then with heparin also served the purpose of investigating the suitability of solid-phase modification to controlled attachment of various polymers. In vivo studies were performed to study the pharmacodynamic behaviour and immunogenicity of solid-phase modified L-asparaginase preparations.

\section{Experimental}

\subsection{Chemicals}

Monomethoxy polyethylene glycol (PEG, MW 5000), bovine liver catalase (EC 1.11.1.6, 4000 units/mg solid), L-asparaginase (Escherichia coli, EC 3.5.1.1, 155 units/mg protein, in 50\% glycerol), malic dehydrogenase (MDH, EC 1.1.1.37, porcine heart, 600 units $/ \mathrm{mg}$ protein) and glutamic oxaloacetate dehydrogenase (GOT, EC 2.6.1.1, 309 units/mg protein), 1,4-butanediol diglycidyl ether (BDGE), carbodiimide (1-ethyl-3-(3-dimethylaminopropyl) carbodiimide hydrochloride) (EDC), cyanuric chloride, Sepharose CL 4-B, heparin (porcine intestinal mucosa, Grade I-A) trinitrobenzene sulfonate (TNBS), and Procion Red H-E 3B were purchased from Sigma (St. Louis, MO, USA).

Nessler's reagent was purchased from Aldrich (Milwaukee, USA). Toluidine blue was from Merck (Darmstadt, Germany).

Balb/C mice were obtained from the Animal Care
Facility of Gulhane Military Medical Academy (Ankara, Turkey).

All the other chemicals used were of analytical grade.

\subsection{Activation of $P E G$}

Activated PEG, 2-4-bis $(O$-methoxy polyethylene glycol)-6-chloro-s-triazine) $\left(\mathrm{PEG}_{2}\right)$, was prepared from monomethoxypolyethylene glycol according to the method of Ona et al. [19]. Monomethoxypolyethylene glycol $(110 \mathrm{~g})$ was dissolved in $500 \mathrm{ml}$ of anhydrous benzene. The solution was refluxed in the presence of granular Molecular Sieves 4 A for 6 $\mathrm{h}$ to remove water. After cooling, zinc oxide (50 g) and cyanuric chloride $(1.85 \mathrm{~g})$ were added, and the mixture was refluxed for $53 \mathrm{~h}$. The resulting mixture was diluted with $500 \mathrm{ml}$ of benzene and filtered. The product $\left(\mathrm{PEG}_{2}\right)$ was precipitated by addition of petroleum ether twice the volume of the solution followed by drying under vacuum to obtain $108 \mathrm{~g}$ of activated PEG.

\subsection{Activation of heparin}

Heparin was activated according to method by Wissink et al. [20]. Heparin (15 mg) was dissolved in an aqueous solution of carbodiimide $(0.8 \mathrm{mM})$ and $N$-hydroxysuccinimide $(0.5 \mathrm{mM})$. The final $\mathrm{pH}$ was adjusted to 5.6 and the solution was stirred for $10 \mathrm{~min}$ at room temperature. The solution was dialyzed for $30 \mathrm{~min}$ against distilled water $(500 \mathrm{ml}$, $\mathrm{pH}$ 5.6) and used immediately for enzyme conjugation.

\subsection{Solid-phase oriented modification of catalase on Procion red-Sepharose}

Procion red-Sepharose CL-4B conjugate was prepared according to the method of Stellwagen et al. [21]. Wet Sepharose CL-4B (20 g) in distilled water $(70 \mathrm{ml})$ was mixed with Procion red HE-3B (200 $\mathrm{mg}$ ) dissolved in distilled $\mathrm{H}_{2} \mathrm{O}(20 \mathrm{ml})$. The mixture was stirred with a glass rod for $5 \mathrm{~min}$. Into the slurry, 
$\mathrm{NaCl}(10 \mathrm{ml}, 20 \%(\mathrm{w} / \mathrm{v}))$ was added and stirred for a further $30 \mathrm{~min}$ at room temperature. Finally, $\mathrm{NaOH}$ $(0.5 \mathrm{ml}, 5 \mathrm{M})$ was added to the mixture and incubated for 3 days while stirring on a magnetic stirrer. Procion red-Sepharose CL-4B was collected on a sintered glass filter and washed sequentially with an excess of deionized water, $\mathrm{NaCl}(1 M)$, urea (4-8 $M$ ) and distilled water.

\subsubsection{Adsorption of catalase on Procion red- Sepharose}

Catalase solution $(5 \mathrm{ml}, 1 \mathrm{mg} / \mathrm{ml})$ in phosphate buffer $(10 \mathrm{~m} M, \mathrm{pH}$ 7.0) was circulated for $1 \mathrm{~h}$ using a peristaltic pump through a column $(1 \times 10 \mathrm{~cm})$ packed with Procion red-Sepharose CL-4B. Enzyme not adsorbed onto the conjugate beads was washed by phosphate buffer (PB) $(10 \mathrm{~m} M, \mathrm{pH} 7.0)$.

\subsubsection{Solid phase $P E G_{2}$ modification}

Cyanuric chloride activated PEG (25 mg) in borate buffer $(5 \mathrm{ml}, 10 \mathrm{mM}$, pH 9.0) was circulated through the column at a flow-rate of $1.5 \mathrm{ml} / \mathrm{min}$ using a peristaltic pump (Master Flex ${ }^{\circledR}$, Cole Parmer Instruments, USA). Unconjugated $\mathrm{PEG}_{2}$ molecules were washed with PB $(30 \mathrm{ml})$.

\subsubsection{Desorption of modified catalase}

In order to elute the solid-phase-modified catalase, $2 M \mathrm{NaCl}$ solution in $\mathrm{PB}(10 \mathrm{~m} M, \mathrm{pH} 7.0)$, was circulated through the system for $1 \mathrm{~h}$. Finally, the eluted enzyme was dialyzed overnight against PB (10 mM, pH 7.0).

The number of $\mathrm{PEG}_{2}$ molecules coupled to the $\varepsilon$-amino groups of catalase was calculated from the difference in the free amino contents of the unmodified enzyme (a native catalase molecule contains 112 amino groups) and that of the modified enzyme.

\section{5. $P E G_{2}$ modification of ASNase on L-asparagine-Sepharose}

Sepharose CL-4B was activated by reaction with 1, 4-butanediol diglycidyl ether $(40 \mathrm{ml})$ and $\mathrm{NaOH}$
(4 1, $0.6 \mathrm{~N}$ ) solution containing sodium borohydride $(0.08 \mathrm{~g})$ [22]. The activation was allowed to proceed at room temperature (RT) for $15 \mathrm{~h}$ in a 0.51 flask in a rotary evaporator. The activated gel was recovered by vacuum filtration, washed seven times with water (1.5 1), and coupled to L-asparagine by the reaction of the gel with L-asparagine $(20 \mathrm{~g})$ in sodium carbonate buffer $(0.5 M, 0.351, \mathrm{pH} 8.5)$. The coupling reaction was allowed to proceed at room temperature for $15 \mathrm{~h}$ with slow rotation in the rotary evaporator. After the coupling step, the gel was washed seven times with water $(1.51)$ and stored in sodium azide $(0.02 \%)$.

\subsubsection{Adsorption of L-asparaginase on activated matrix}

Wet asparagine-Sepharose CL-4B (5 g) was packed into an affinity column $((1 \times 10 \mathrm{~cm}$, Amersham Pharmacia Biotech, Sweden) and equilibrated with phosphate buffer $(10 \mathrm{~m} M, \mathrm{pH} 7.0)$. L-Asparaginase solution $(5 \mathrm{ml}, 0.6 \mathrm{mg}$ ) was circulated by a peristaltic pump through the column for $1 \mathrm{~h}$. Unadsorbed enzyme was washed away with phosphate buffer (10 $\mathrm{mM}, \mathrm{pH}$ 8.5) until no protein appeared in the wash (about $30 \mathrm{ml}$ ).

\subsubsection{Solid phase $P E G_{2}$ modification}

Activated PEG (25 mg) was dissolved in borate buffer ( $5 \mathrm{ml}, 10 \mathrm{mM}, \mathrm{pH} 9.5$ ) and circulated through the affinity column for $1 \mathrm{~h}$ at $17^{\circ} \mathrm{C}$. Unconjugated $\mathrm{PEG}_{2}$ molecules were removed by phosphate buffer (10 $\mathrm{m} M, \mathrm{pH}$ 7.0) from the column.

\subsubsection{Desorption of $P E G_{2}$-modified asparaginase}

$\mathrm{NaCl}$ solution $(0.5 M)$ containing L-asparagine (20 $\mathrm{m} M$ ) was circulated through the affinity column to desorb the adsorbed enzyme until absorbance of the enzyme in eluent became steady (about $35 \mathrm{~min}$ ).

The number of $\mathrm{PEG}_{2}$ molecules coupled to $\varepsilon$-amino groups of asparaginase was calculated from the difference in the amino content of the unmodified enzyme (a native asparaginase molecule contains 92 amino groups) and that of the modified enzyme.

\subsection{Sequential solid-phase modification of ASNase first with $\mathrm{PEG}_{2}$ and then with heparin}

Solid phase $\mathrm{PEG}_{2}$ modification of ASNase was 


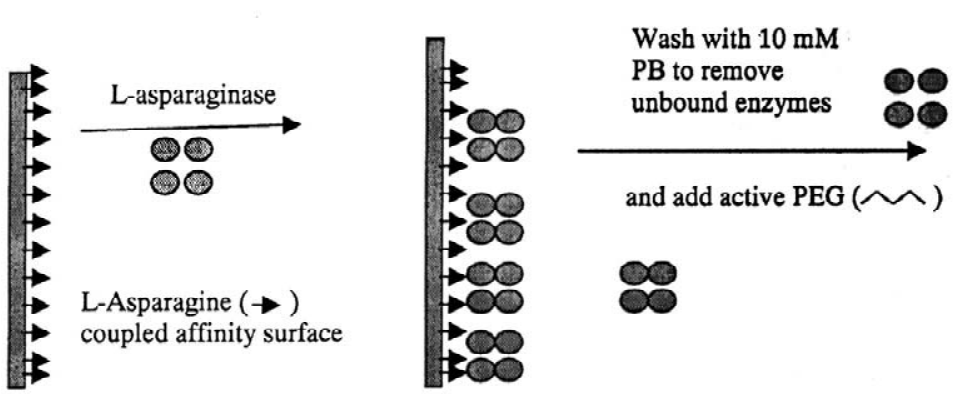

Adsorption of asparaginase

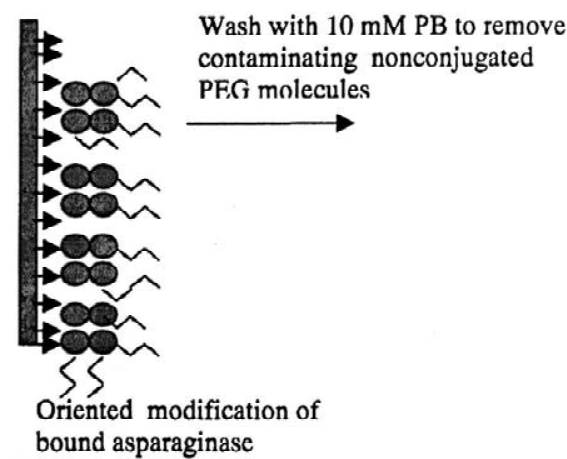

Wash with $10 \mathrm{mM}$ PB to remove contaminating nonconjugated PF.G molecules
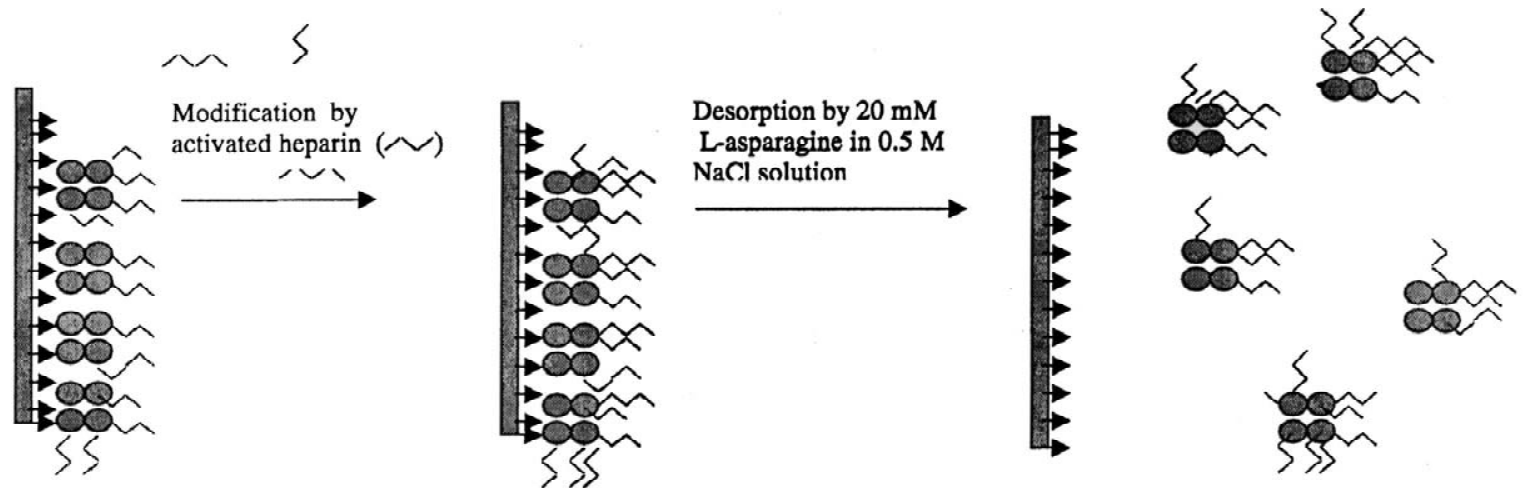

Fig. 1. Successive solid-phase modification of L-asparaginase.

done as described in Section 2.5. For sequential coupling of activated heparin (Fig. 1), column was washed with $30 \mathrm{ml}$ distilled water $(\mathrm{pH}$ was adjusted to 5.6 with $\mathrm{HCl}$ ) after $\mathrm{PEG}_{2}$ modification. Then, 5 $\mathrm{ml}$ of dialyzed aqueous active heparin solution (20 $\mathrm{mg}, \mathrm{pH}$ 5.6) was circulated through the column for 30 min. Desorption of $\mathrm{PEG}_{2}$ and heparin conjugated ASNase was achieved by circulating $4 \mathrm{ml}$ sodium chloride solution $(0.5 \mathrm{M}$, containing $20 \mathrm{~m} M$ L-asparagine) for $30 \mathrm{~min}$. The modified ASNase solution was dialyzed overnight in PBS at $4{ }^{\circ} \mathrm{C}$.

\subsection{Measurement of catalase and ASNase activity}

\subsubsection{Specific activity of catalase}

The activity of catalase was determined spectrophotometrically by measuring the decrease in absorbance of $\mathrm{H}_{2} \mathrm{O}_{2}$ at $240 \mathrm{~nm}$ [23]. Enzyme solution
$(25 \mu \mathrm{l})$ was mixed with $\mathrm{H}_{2} \mathrm{O}_{2}(3 \mathrm{ml}, 15 \mathrm{mM}$ in 50 $\mathrm{m} M$ phosphate buffer, $\mathrm{pH} 7$ ) and the decrease in absorbance in $2-3 \mathrm{~min}$ at $25^{\circ} \mathrm{C}$ was recorded with a UV-Vis spectrophotometer (Shimadzu, Model 2100). The specific activity, $\mathrm{U} / \mathrm{mg}$ protein, was calculated using the extinction coefficient for $\mathrm{H}_{2} \mathrm{O}_{2}$ of $0.0447 \mathrm{mM} M^{-1} \mathrm{~cm}^{-1}$ from the equation given below

Specific Activity $(\mathrm{U} / \mathrm{mg}$ protein $)=\left(\Delta A_{240} / \mathrm{min}\right)$ $(3025 \mu \mathrm{l})(0.0447)^{-1}(25 \mathrm{ml})^{-1}(\mathrm{mg} \text { prot. in } 25 \mu \mathrm{l})^{-1}$

\subsubsection{Specific activity of L-asparaginase in situ and in vivo}

In situ L-asparaginase activities were measured by Nessler's method. The assay procedure is based on direct Nesslerization of ammonia [24]. Enzyme solution $(10-100 \mu \mathrm{l})$ was added to Tris- $\mathrm{HCl}(\mathrm{pH}$ 
$8.5,50 \mathrm{~m} M)$ in a final volume of $1.5 \mathrm{ml}$. The reaction was started with addition of L-asparagine solution $(0.5 \mathrm{ml}, 10 \mathrm{mM}$, in $50 \mathrm{~m} M$ Tris $-\mathrm{HCl}, \mathrm{pH}$ 8.5 ) and allowed to proceed for $5-60 \mathrm{~min}$ at $37^{\circ} \mathrm{C}$. The incubation was stopped with trichloroacetic acid $(0.5 \mathrm{ml}, 15 \%)$ and the volume was adjusted to $4.5 \mathrm{ml}$ with distilled water. Nessler's reagent $(0.5 \mathrm{ml})$ was added, and the mixture was allowed to stand at room temperature for $15 \mathrm{~min}$, and then the absorbance at $500 \mathrm{~nm}$ was measured with UV-Vis spectrophotometer.

The extinction coefficient of $\mathrm{NH}_{4} \mathrm{Cl}$ (used as a standard ammonia) was found to be $0.1383 \mu \mathrm{M}^{-1}$ $\mathrm{cm}^{-1}$.

L-asparaginase specific activity (Unit) was calculated as: $\left(\Delta A_{500} / \mathrm{min}\right) /(0.1383) / \mathrm{mg}$.

To measure L-asparaginase activity in the serum of mice, coupled enzyme assay was used due to the higher sensitivity of the method compared with Nessler's method [25]. The enzyme mixture was prepared by mixing glycerol $(100 \mathrm{ml}, 87 \%)$, Tris$\mathrm{HCl}$ buffer ( $\mathrm{pH} 8.45,50 \mathrm{ml}, 0.5 \mathrm{M})$, NADH (50 $\mathrm{mg}), \alpha$-ketoglutaric acid $(50 \mathrm{mg})$, GOT (180 U), MDH (110 U) and the volume was adjusted to 500 $\mathrm{ml}$ with distilled water. Asparaginase containing plasma $(50 \mu \mathrm{l})$ was added into this enzyme-coupled activity assay mixture $(2.25 \mathrm{ml})$ and incubated for 15 $\min$ at $37^{\circ} \mathrm{C}$. Then, $250 \mu \mathrm{l} 10 \mathrm{mM}$ L-asparagine in Tris- $\mathrm{HCl}$ buffer, $\mathrm{pH} 8.5$, was added and the reduction in absorbance of NADH was recorded at $340 \mathrm{~nm}$ using UV-visible spectrophotometer.

The concentration of native and modified enzymes were calculated by the use of Lowry protein determination method [26].

\subsection{Determination of the degree of modification of enzymes with $P E G_{2}$}

The degree of modification with $\mathrm{PEG}_{2}$ was determined through quantifying the amino groups in the modified enzyme by reaction with trinitrobenzene sulfonate (TNBS). An enzyme solution $(250 \mu \mathrm{l}, 0.5$ $\mathrm{mg}$ protein $/ \mathrm{ml}$ ) was mixed with sodium bicarbonate buffer $(250 \mu l, 0.5 M, \mathrm{pH} 8.5)$ and then an aqueous solution of trinitrobenzene sulfonate $(250 \mu 1,0.1 \%)$ was added. The mixture was incubated at $40{ }^{\circ} \mathrm{C}$ for 2 $\mathrm{h}$ to complete the reaction. After adding SDS (250 $\mu 1,10 \%)$ and $\mathrm{HCl}(125 \mu \mathrm{l}, 1 \mathrm{M})$, the absorbance of the solution at $335 \mathrm{~nm}$ was measured. A standard curve was obtained using glycine solutions (0-1 $\mathrm{m} M)$. The degree of modification is obtained by dividing the number of modified free amino groups by the total number of amino groups in the unmodified enzyme molecule.

\subsection{Determination of heparin concentration}

The amount of heparin conjugated to asparaginase was estimated by the Toluidine blue reaction as described by Smith et al. [27]. PEG $_{2}$-Heparin-ASNase sample $(0.1 \mathrm{ml})$ was added into Toluidine blue solution $(2.5 \mathrm{ml}, 0.005 \%, 0.01 \mathrm{~N} \mathrm{HCl}$ containing $0.2 \% \mathrm{NaCl}$ ) in a test tube. The mixture was vortexed vigorously for $30 \mathrm{~s}$. It was diluted with $\mathrm{NaCl}(0.2 \%)$ to a total volume of $5 \mathrm{ml}$ and agitated by a vortex mixer for $30 \mathrm{~s}$. Hexane $(5 \mathrm{ml})$ was then added to each tube and the tubes were shaken vigorously for another $30 \mathrm{~s}$ to separate the heparin-dye complex formed. Aqueous solution $(0.5 \mathrm{ml})$ was mixed with ethanol $(2.5 \mathrm{ml})$ and the absorbance was measured at $621 \mathrm{~nm}$ by using UV-visible spectrophotometer. To construct a standard curve with a concentration range of approximately $10-70 \mu \mathrm{g}$ of heparin, varying amounts of heparin in saline solution $(2.5 \mathrm{ml} 0.2 \%)$ were prepared and mixed with the dye solution (2.5 $\mathrm{ml}$ ). For the assessment of the number of heparin molecules bound on each asparaginase molecule, the average molecular masses for heparin and asparaginase were assumed to be 19000 and $136000 \mathrm{Da}$, respectively.

\subsection{Determination of in vivo half-life of ASNase preparations}

Studies to measure the residence of modified and unmodified asparaginase in the circulation were undertaken using female Balb-C mice. The animals were housed in the Animal Care Facility (METU), in an air-conditioned room with a $12 \mathrm{~h}$ light/12 h dark cycle. $\mathrm{PEG}_{2}$ modified L-asparaginase $(0.5 \mathrm{ml}, 1.2 \mathrm{U})$ or unmodified free asparaginase $(0.5 \mathrm{ml}, 30 \mathrm{U})$ in 
PBS was injected to the dilated lateral vein of mice. By using opposite lateral vein, blood samples were collected into heparin $(10 \mu \mathrm{l}, 5 \mathrm{mg} / \mathrm{ml})$ containing plastic microtubes. After centrifugation, $50 \mu \mathrm{l}$ of plasma was collected and added into enzyme assay mixture $(2.25 \mathrm{ml})$ (for coupled enzyme activity assay). After incubating plasma in enzyme assay mixture $15 \mathrm{~min}$ at $37^{\circ} \mathrm{C}$, substrate solution $(0.25 \mathrm{ml}$, $10 \mathrm{mM}$ ) was added and the reaction was started for asparaginase activity measurement.

\subsection{Antigenicity of ASNase preparations}

For toxicity studies, four Balb-C mice for solidphase PEG-modified and three for unmodified ASNase, were sensitized with subcutaneous injections of $100 \mu \mathrm{g}$ of unmodified, and $\mathrm{PEG}_{2}$-modified ASNase on days 0,10 , and 20 [28]. On day 30, animals were challenged with the same dose of free and PEG-modified enzyme given by intravenous injection through their tail vein. Deaths and symptoms of hypersensitivity were recorded.

\section{Results and discussion}

\section{1. $P E G_{2}$ modification of catalase on Procion red-Sepharose $C L-4 B$}

For solid-phase modification of catalase, a specific affinity column aimed to protect the active site of the enzyme was prepared and the enzyme was modified with activated polyethylene glycol. Procion Red H-E 3B dye molecule was reported to bind the empty NADPH cofactor space near the catalytic site of catalase (some subunits of catalase were detected to have no cofactor) [29]. As seen in Fig. 2, the number of attached $\mathrm{PEG}_{2}$ increased almost linearly with the reaction time. At the end of a $1 \mathrm{~h}$ reaction time with $\mathrm{PEG}_{2}, 75$ molecules of $\mathrm{PEG}_{2}$ were conjugated per catalase molecule (75 per 112 amino groups occupied). In the same figure it is shown that as the conjugation of $\mathrm{PEG}_{2}$ increases, the specific activity of catalase decreases in almost linear fashion. Some subunits in tetrameric catalase molecule may not be protected by the affinity matrix during $\mathrm{PEG}_{2}$ modification due to the globular structure of enzyme.

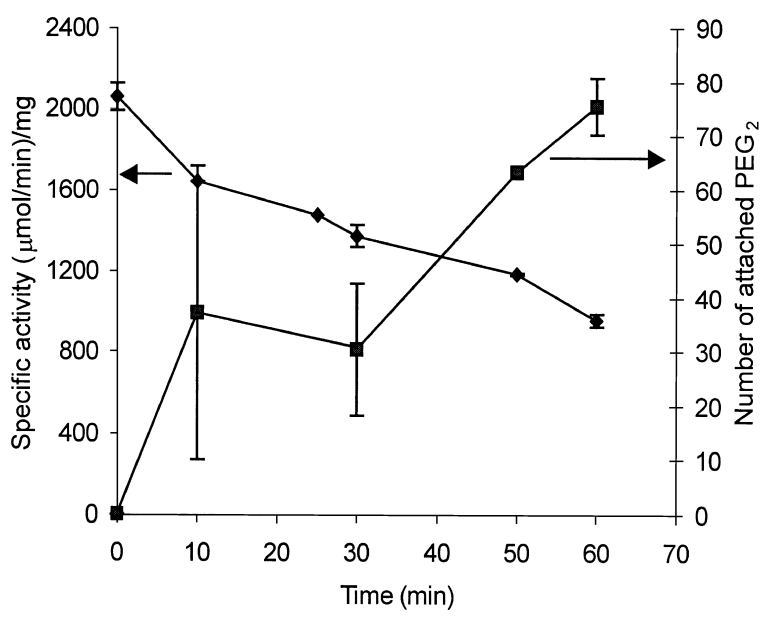

Fig. 2. Specific activity $(-\downarrow)$ and number of coupled $\mathrm{PEG}_{2}$ molecules (-口-) at specified times of solid-phase $\mathrm{PEG}_{2}$ modification of catalase on Procion red-Sepharose. ( $n=2$ for specific activity and $n=3$ for attached PEG determination. Modifications were performed at $17^{\circ} \mathrm{C}$ with a $\mathrm{PEG}_{2}$ flow-rate of $1.5 \mathrm{ml} / \mathrm{min}$ ).

Specific activity vs. modification time showed small differences in batches. As seen from the error bars of specific activity which correspond to two independent solid-phase preparations, the batch differences are quite small. This indicated that solid-phase modification yields quite homogenous $\mathrm{PEG}_{2}$-protein conjugates at the end of the process. Other advantages of solid-phase enzyme modification are presented in Table 1.

\section{2. $P E G_{2}$ modification of ASNase}

In order to monitor the kinetics of enzyme adsorption, and possible changes during $\mathrm{PEG}_{2}$ modification of solid-phase ASNase, a flow-through cell was connected to the outlet of an affinity column. Fig. 3 shows a rapid adsorption of the enzyme on the affinity matrix (removal from circulating solution); adsorption was accomplished within a few minutes and there was no change in the unadsorbed protein level after the 10th min indicating the efficiency of the system. It was seen that during the modification with $\mathrm{PEG}_{2}$ the enzyme was not desorbed or did not leak from its affinity matrix. This indicates a strong adsorption by L-asparaginase on the matrix. 
Table 1

Advantages and disadvantages of solid-phase oriented enzyme modification and free enzyme modification methods

\begin{tabular}{ll}
\hline Solid-phase oriented enzyme modification & Free enzyme modification \\
\hline $\begin{array}{l}\text { Active sites of enzymes can be protected } \\
\text { from modification by active polymer }\end{array}$ & $\begin{array}{l}\text { As the reaction proceeds randomly in nature, active sites can } \\
\text { be harmed by the modification. Enzyme activity may be lost } \\
\text { By keeping column temperature and flow-rate }\end{array}$ \\
$\begin{array}{l}\text { Modification level is adjusted by a ratio of } \\
\text { enzyme functional group/active reagent. As } \\
\text { the reaction can not be stopped instantaneously, } \\
\text { can be avoided. Washing of active reagents is instantaneous, } \\
\text { for that reason the level of modification is constant at }\end{array}$ & $\begin{array}{l}\text { batch differences by random modification is } \\
\text { quite possible. }\end{array}$ \\
$\begin{array}{l}\text { specified conditions. } \\
\text { Modification control is easy. The modification can be stopped }\end{array}$ & $\begin{array}{l}\text { By changing reaction medium (sudden pH changes, neutralizing } \\
\text { chemicals) modification can be stopped, but it is not instantaneous. }\end{array}$ \\
by simple column washing. & $\begin{array}{l}\text { Since there are active reagents and reaction by-products, } \\
\text { the purification process requiring long and tedious purification } \\
\text { Modified enzyme can be desorbed from column in pure form. }\end{array}$ \\
\end{tabular}

Fig. 4 presents the desorption profile of L-asparaginase after modification with $\mathrm{PEG}_{2}$ from the affinity matrix by $0.5 \mathrm{M} \mathrm{NaCl}$ containing $20 \mathrm{mM}$ asparagine. Desorption was achieved in about 10 min. Since the desorption solution was circulated in a closed loop, the equlibration of the desorbed protein with the circulating solution required some time and within $30 \mathrm{~min}$ removal was completed. The number of $\mathrm{PEG}_{2}$ molecules attached per molecule of asparaginase was determined using TNBS. A $1 \mathrm{~h}$ solid-phase modification resulted in the conjugation of $69.6 \mathrm{PEG}_{2}$ molecules per asparaginase molecule and $50.2 \%$ of the original specific activity was recovered in the desorbed asparaginase eluate (Table

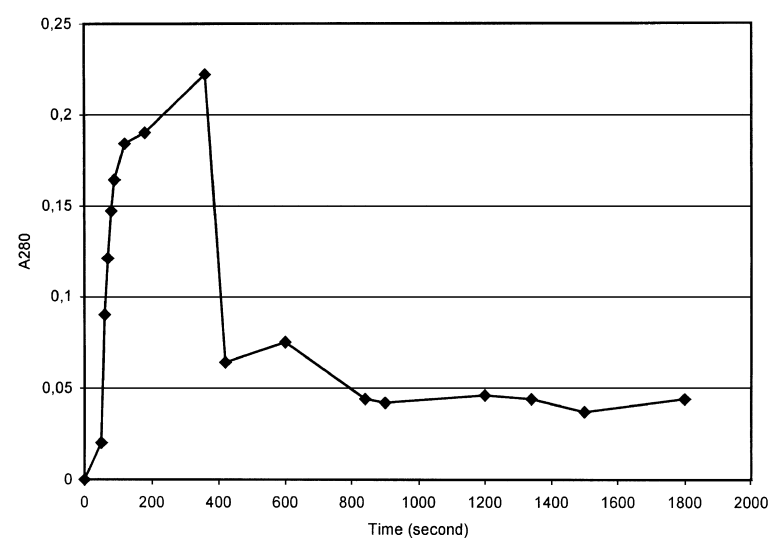

Fig. 3. Adsorption profile of ASNase (- - ) on asparagine-Sepharose column (Test temperature: $17^{\circ} \mathrm{C}$, Enzyme Flow Rate: 1.5 $\mathrm{ml} / \mathrm{min})$.
$2)$. The specific activities of the unmodified and modified asparaginase were $147.0 \mathrm{U} / \mathrm{mg}$ and 73.8 $\mathrm{U} / \mathrm{mg}$ protein, respectively.

$\mathrm{PEG}_{2}$ modification of asparaginase on asparagineSepharose-CL-4B was achieved with the attachment of about $69 \mathrm{PEG}_{2}$ molecules per asparaginase molecule with a retention of $50.2 \%$ specific activity for a $1 \mathrm{~h}$ of reaction time. Enzyme was partially protected from inactivation by $\mathrm{PEG}_{2}$ modification process by binding it to affinity column. Inada et al. [15], reported $10 \%$ residual specific activity after $57 \%$ modification of asparaginase (52 of 92 amino groups on the enzyme were modified) with cyanuric chloride activated PEG. This result clearly shows that in

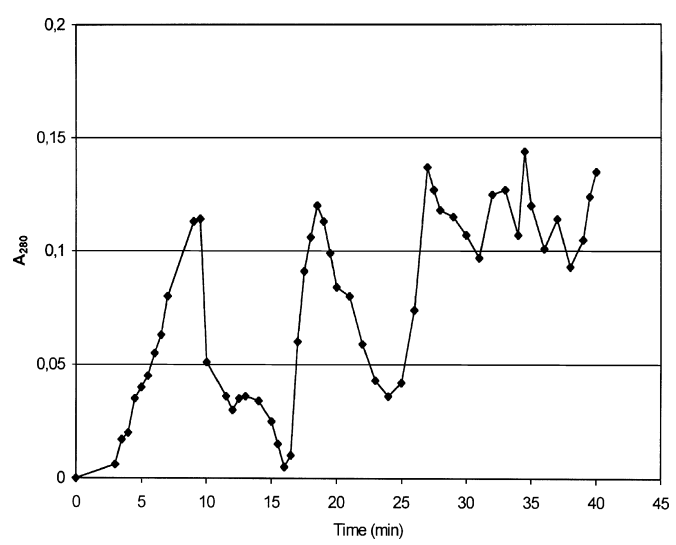

Fig. 4. Desorption profile of $\mathrm{PEG}_{2}$-modified L-asparaginase (- - -) from asparagine-Sepharose by $0.5 \mathrm{M} \mathrm{NaCl}$ containing $20 \mathrm{mM}$ L-asparagine. (Flow rate: $1.5 \mathrm{ml} / \mathrm{min}$ ). 
Table 2

Changes in the activity and specific activity of asparaginase during solid-phase modification to PEG-ASNase

\begin{tabular}{llccc}
\hline $\begin{array}{l}\text { Steps } \\
\text { in solid-phase } \\
\text { modification }\end{array}$ & $\begin{array}{l}\text { Total activity } \\
\text { (Unit) }\end{array}$ & $\%$ Activity & $\begin{array}{l}\text { Specific activity } \\
\text { (Unit/mg) }\end{array}$ & $\%$ Specific activity \\
\hline Before adsorption & 78.8 & 100 & 147.0 & 100 \\
Supernatant & 6.0 & 7.6 & - & - \\
Desorbed PEG-ASNase & 18.6 & 23.6 & - & 50.25 \\
Washing & 15.6 & 19.8 & - \\
\hline
\end{tabular}

Solid-phase modification conditions: $\mathrm{PEG}_{2}(5 \mathrm{mg} / \mathrm{ml}, \mathrm{pH} 9.5)$ at $17^{\circ} \mathrm{C}$ and $1 \mathrm{~h}$ circulation.

the present study the asparagine-Sepharose matrix efficiently protected the active sites of the asparaginase against the detrimental effects of $\mathrm{PEG}_{2}$ modification by orienting the active site of the subunit away from the mobile phase and towards the solid matrix. The active form of asparaginase is composed of four identical subunits, A, B, C, and D [30]. Since the enzyme is tetrameric and globular it is not possible to attach all the subunits to the affinity matrix. Consequently, the active sites of some subunits may not be protected against $\mathrm{PEG}_{2}$ modification and the inactivation of those subunits is probably the cause of the decrease in the specific activity.

\subsection{Determination of in vivo half life of ASNase preparations}

One of the aims of this study was to increase the half-life and prevent the toxicity of L-asparaginase in the circulation by modifying with polyethylene glycol and heparin on a solid-phase affinity matrix, L-asparagine-Sepharose CL-4B. To assess the pharmacokinetic properties of $\mathrm{PEG}_{2}$ modified ASNase and $\mathrm{PEG}_{2}$-heparin conjugated ASNase these preparations were introduced to the blood circulation of Balb/C mice. Unmodified ASNase showed a very sharp clearance from the circulation as shown in Fig. 5. Slightly less than $50 \%$ of the activity remained after $10 \mathrm{~h}$ of circulation, a value very close to the half-life of $11 \mathrm{~h}$ reported in the literature [24].

Solid-phase $\mathrm{PEG}_{2}$ modified ASNase, however, showed a prolonged clearance from the circulation (Fig. 5). Even after 2 days, more than $50 \%$ of the activity was still in circulation.

Although the half-life obtained with $\mathrm{PEG}_{2}$ modified ASNase by Inada et al. [15] was similar to our result ( 56 vs. 50 h) their preparation had only $10 \%$ of the original specific activity whereas our preparation retained its specific activity to a level of $50.2 \%$ of the original. The high specific activity in our preparation must be the result of the differences in the PEGylation procedures. It seems that asparagineSepharose CL-4B affinity column significantly protects the active sites of ASNase.

Sequential $\mathrm{PEG}_{2}$ and heparin conjugation was achieved on affinity matrix of $\mathrm{L}$-asparaginase. Asparaginase modified for $1 \mathrm{~h}$ with $\mathrm{PEG}_{2}$ and then conjugated with heparin had about nine molecules of heparin per asparaginase molecule. The residence half-lives $\left(t_{1 / 2}\right)$ of unmodified, $\mathrm{PEG}_{2}$-conjugated ASNase, and $\mathrm{PEG}_{2}$-heparin conjugated ASNase in

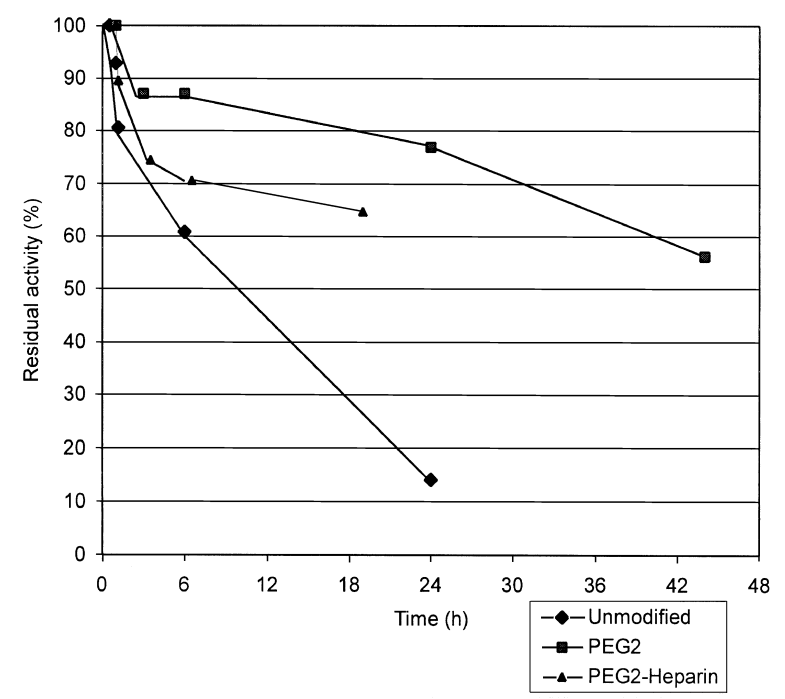

Fig. 5. Residual activity of unmodified (- $\downarrow$ ), solid-phase $\mathrm{PEG}_{2}$ modified (-口-), and solid-phase $\mathrm{PEG}_{2}$ and heparin conjugated (- $\mathbf{\Delta}-)$ ASNase in blood serum of mice. Injected doses: Native ASNase: $30 \mathrm{U}, \mathrm{PEG}_{2}$-ASNase: $1.2 \mathrm{U}, \mathrm{PEG}_{2}$-Hep-ASNase: $1.3 \mathrm{U}$. 
the circulation were 10,50 and $25 \mathrm{~h}$, respectively. Compared with only- $\mathrm{PEG}_{2}$ conjugate, however, the residence time of the ASNase modified by $\mathrm{PEG}_{2}$ and heparin was decreased (half-lives $50 \mathrm{~h}$ with PEGASNase whereas $25 \mathrm{~h}$ with PEG-heparin-ASNase). Since, heparin is a negatively charged host-polymer and some cell types have heparin receptors, heparin attachment probably rendered asparaginase molecule more recognizable by endothelial cells and polymorphonuclear leukocytes. Nevertheless, the experiment showed the suitability of solid-phase modification to sequential conjugation of polymers to change the biological properties of enzyme molecules and target these pharmaceutical proteins to specific body sites.

In conclusion, solid-phase $\mathrm{PEG}_{2}$ modification of ASNase produced a very long circulatory-half life compared to unmodified ASNase preparations and heparin conjugation decreased this to some extent.

\subsection{Antigenicity testing for ASNase preparations}

In order to test the antigenicity, modified and native ASNase were introduced to mice by three subcutaneous (s.c) and one intravenous (i.v.) injections (challenge). Subcutaneous injections were for the sensitization of the animals before the i.v injection. When the native ASNase was injected, two of the three mice showed typical anaphylaxis and died within $30 \mathrm{~min}$. Upon injection of modified ASNase, however, no adverse effects or symptoms of anaphylaxis were observed. These results indicate that solid-phase modification of enzymes on their affinity matrix prevented hypersensitivity reactions by covering antigenic sites of the enzyme by nonimmunogenic $\mathrm{PEG}_{2}$ molecules and made them more suitable for pharmaceutical applications.

This study indicated that modification of enzymes by solid-phase oriented and non-random modification method presents important advantages both in practical applications (therapeutic) and basic enzymology: the accuracy of modification level (number of coupled polymers), protection of active sites from reactive polymers, desorption of pure modified enzyme from the affinity column thereby, not requiring extensive time consuming purification steps, and enabling a flexibility in subsequent modification of adsorbed enzyme by various polymers to change physical and biological properties of enzymes.

\section{Conclusion}

Solid-phase oriented enzyme modification employing catalase as a model enzyme was performed on the affinity medium Procion red-Sepharose. A significant amount of PEG was bound on the enzyme after $1 \mathrm{~h}$ reaction time ( 75 molecules of $\mathrm{PEG}_{2}$ per 112 amino groups) and the results were reproducible. The retention of specific activity was at the level of $46.5 \%$

The same approach was then tested on the antileukemic enzyme asparaginase using asparagineSepharose-CL-4B system as the solid support. A very significant level of occupation of the available amine groups was achieved with the attachment of about $69 \mathrm{PEG}_{2}$ molecules per asparaginase molecule with a retention of $50.2 \%$ specific activity within $1 \mathrm{~h}$ of reaction time.

Both these enzymes revealed that site-directed immobilization followed by PEG attachment retained a significantly higher fraction of the activity of the enzyme in question

The literature reveals that when L-asparagine was modified with PEG 5000 activated by succinimidyl succinate, the PEG-enzyme could retain only $30 \%$ of the original activity of nonmodified asparaginase and the extent of modification of amino groups in the molecule was determined to be 50 amino groups [31].

In another study L-asparaginase from Escherichia coli was modified with 2,4-bis $(O$-methoxypolyethylene glycol)-6-chloro-s-triazine (activated $\mathrm{PEG}_{2}$ ) [32]. The $\mathrm{PEG}_{2}$-modified asparaginase retained approximately $30 \%$ ( $73 \mathrm{IU} / \mathrm{mg}$ of protein) of the enzymic activity of the native enzyme, while it had almost completely lost its immunoreactivity towards anti-asparaginase antibodies.

E. coli asparaginase was modified with poly $(N-$ vinylpyrrolidone-co-maleic anhydride) approximately $69 \%$ of amino groups were modified but it retained only $8.3 \%$ of the native L-asparaginase activity [33].

All these studies had low yields of modification 
and low retention of enzymatic activity revealing that site direction and modification on solid supports is a very effective way of enzyme modification.

ASNase could also be successfully and sequentially modified by first $\mathrm{PEG}_{2}$ and then heparin. With this approach about nine molecules of heparin could be covalently attached per asparaginase molecule. This again is a proof of the effectiveness of the method.

Pharmacokinetic properties of solid-phase PEG modified ASNase preparations were studied in the blood circulation of mice. Unmodified ASNase showed a very sharp clearance from the blood. Less than $50 \%$ of the activity remained after $10 \mathrm{~h}$ in the circulation. PEG-ASNase, on the other hand, showed a prolonged circulation. Even after 2 days, more than $50 \%$ of the enzyme could be detected in the blood. The residence time of the $\mathrm{PEG}_{2}$ and heparin conjugated ASNase was in between the PEG-ASNase and the untreated enzyme. After $10 \mathrm{~h}$ the residual enzyme content was around $70 \%$. This could partially be explained by heparin interfering with the contribution of PEG in terms of hydrophilicity and surface coverage of the enzyme. In that sense this test showed that sequential modifications could be achieved but their effects may not always be synergistic.

No adverse effects or symptoms of anaphylaxis were observed upon injection of $\mathrm{PEG}_{2}$-ASNase while the unmodified ASNase, resulted in hypersensitivity reactions in two out of the three mice tested. This revealed that surface masking of the enzyme through conjugation with $\mathrm{PEG}_{2}$ is very important when its use as an anticancer agent is contemplated. All these results indicate that solidphase oriented modification of enzyme is successful in preventing the detrimental effects of conjugation processes on the activity of the enzyme and it prolongs the circulation half-life and prevents the immunogenicity of the enzyme. In all this is a successful approach that has a potential for use in experimental cancer therapy studies.

\section{Acknowledgements}

This work was supported by a grant from the Middle East Technical University Graduate School of Natural and Applied Sciences (Grant METU AFP99-06-02-23).

\section{References}

[1] Y. Kodera, A. Matsushima, M. Hiroto, H. Nishimura, A. Ishii, T. Ueno, Y. Inada, Prog. Polym. Sci. 23 (1998) 1233.

[2] G. Qian, J. Ma, J. Zhou, B. He, React. Funct. Polym. 32 (1997) 117.

[3] J. Kurtzberg, B. Asselin, D. Poplack, A. Grenbanier, R. Chen, Cancer Invest. 12 (1994) 59.

[4] S.L. Berg, F.M. Balis, C.L. McCully, K.S. Godwin, D.G. Poplack, Cancer Chemother. Pharmacol. 32 (1993) 310.

[5] J. Turkova, J. Chromatogr. B 722 (1999) 11.

[6] M. Fusek, J. Turkova, J. Stovickova, F. Frank, Biotechnol. Lett. 10 (1988) 85.

[7] L. Petkov, J. Sajdek, K. Rae, M. Suchova, J. Kas, J. Turkova, Biotechnol. Tech. 4 (1990) 25.

[8] J. Turkova, L. Petkov, J. Sajdok, J. Kas, M.J. Benes, J. Chromatogr. 500 (1990) 585.

[9] R.M. Blanco, J.J. Calvete, J.M. Guisan, Enzyme Microb. Technol. 11 (1989) 353.

[10] J. Turkova, M. Fusek, J. Stovickova, Z. Kralova, Chem. Macromol. Symp. 17 (1988) 241.

[11] D.A. Butterfield, D. Bhattacharyya, S. Daunert, L. Bachas, J. Memb. Sci. 181 (2001) 29.

[12] R.B. Greenwald, J. Controlled Release 74 (2001) 159.

[13] S. Mumtaz, B.K. Bachhawat, J. Biochem. Biophys. 28 (1991) 346.

[14] A. Matsushima, Y. Kodera, M. Hiroto, H. Nishimura, Y. Inada, J. Mol. Catal. B: Enzyme 2 (1996) 1.

[15] Y. Inada, A. Matsushima, Y. Kodera, H. Nihhimura, Methods Enzymol. 283 (1994) 65.

[16] A. Martinez, A. Pendri, J. Xia, R.B. Greenwald, Macromol. Chem. Phys. 198 (1997) 2489.

[17] G. Fortier, M. Laliberte, Biotechnol. Appl. Biochem. 17 (1993) 115.

[18] S. Lentsch, P. Aimar, J.S. Orazco, Biotechnol. Bioeng. 41 (1993) 1039.

[19] K. Ono, Y. Kai, H. Maeda, F. Samizo, K. Sakurai, H. Nishimura, Y. Inada, J. Biomater. Sci., Polym. Ed. 2 (1991) 61.

[20] M.J.B. Wissink, R. Beernink, J.S. Pieper, A.A. Poot, G.H.M. Engbers, T. Beugeling, W.G. van Aken, J. Feijen, Biomaterials 22 (2001) 151.

[21] E. Stelwagen, Methods Enzymol. 182 (1990) 343.

[22] S. Lee, M.H. Wrobe, J.T. Ross, Appl. Biochem. Biotechnol. 22 (1989) 1.

[23] H. Aebi, Methods Enzymol. 105 (1984) 121.

[24] J.C. Wriston, Methods Enzymol. 113 (1985) 608.

[25] N.H. Jayaram, D.A. Cooney, S. Jayaram, L. Rosenblum, Anal. Biochem. 59 (1974) 327.

[26] O.H. Lowry, N.J. Rosebrough, A.L. Farr, R.J. Randall, J. Biol. Chem. 193 (1951) 265. 
[27] P.K. Smith, A.K. Mallia, G.T. Hermanson, Anal. Biochem. 109 (1980) 466.

[28] J.C.S. Jorge, R. Perez-Soler, J.G. Morais, M.E.M. Cruz, Cancer Chemother. Pharmacol. 34 (1994) 230.

[29] H.M. Jouve, J. Pelmolt, J. Gaillard, Arch. Biochem. Biophys. 248 (1986) 71.

[30] A.L. Swain, M. Jaskolski, D. Housset, J.K.M. Rao, A. Wlodawer, Proc. Natl. Acad. Sci. USA 90 (1993) 1474.
[31] A.L. Soares, G.M. Guimaraes, B. Polakiewicz, R.N.M. Pitombo, J.A. Neto, Int. J. Pharm. 237 (2002) 163.

[32] T. Yoshimoto, H. Nishimura, Y. Saito, K. Sakurai, Y. Kamikasi, H. Wada, M. Sako, G. Tsujino, Y. Inada, Jpn. J. Cancer Res. 77 (1986) 1264.

[33] G. Qian, J. Ma, J. Zhou, B. He, React. Funct. Polym. 32 (1997) 117. 